Article

\title{
Eating and Being Eaten: Interspecies Vulnerability as Eucharist
}

\section{Lisa Dahill}

Religion, College of Arts and Sciences, California Lutheran University, Thousand Oaks, CA 91360, USA; ldahill@callutheran.edu

Received: 7 March 2020; Accepted: 14 April 2020; Published: 20 April 2020

\begin{abstract}
Living in a time of urgent ecological crisis, Christians need outdoor ritual experience of their faith: of what is wild, of the living Earth, stranger faces of the divine: taking eco-alienated people out of the building and into the streets, the river, the forest. Moving liturgy outdoors makes possible an opening to both human and more-than-human strangeness on their own terms, in actual, present, sensory experience. It also opens worshipers' experience of the Christian sacraments into the disconcerting realm of our bodies' physical edibility to other creatures: the possibility of our own flesh becoming food. Using the work of Val Plumwood, David Abram, and Eric Meyer, this paper examines Eucharistic ritual language and theologies of resurrection as these contribute to a worldview that maintains a human versus food dualism incommensurate with biological processes. Ultimately, the paper calls for Eucharistic practices that allow participants to pray being prey.
\end{abstract}

Keywords: predation; food; ecology; Eucharist; Earth; sacrament; ritual; resurrection; Plumwood; Abram

\section{Introduction: Being Eaten}

It is not a minor or inessential feature of our human existence that we are food: juicy, nourishing bodies.

Val Plumwood, "Meeting the Predator," in Eye of the Crocodile. 10.

For some time, I have been exploring the question of what happens when Christian liturgy moves outdoors, into engagement with the more-than-human natural world. Living in a time of urgent ecological crisis, Christians need outdoor ritual experience of their faith: of what is wild, of the living Earth, stranger faces of the divine: taking eco-alienated people out of the building and into the streets, the river, the forest. Moving liturgy outdoors makes possible an opening to both human and more-than-human strangeness on their own terms, in actual, present, sensory experience.

It also opens worshipers' experience of the Christian sacraments into the disconcerting realm of our bodies' physical edibility to other creatures: the possibility of our own flesh becoming food. Australian philosopher Val Plumwood is among those who have thought most deeply and broadly on the topic of human edibility, in the wake of her 1985 experience of a near-fatal crocodile attack. ${ }^{1}$ Somehow surviving three death-rolls before managing to break free and crawl miles to rescue, Plumwood experienced her normal perceptual world collapsing violently into the primal physicality of her body being taken as food for another animal. In subsequent years, she reflected deeply on the raw shock of that: how she, like most contemporary humans well buffered from the natural world, had unconsciously defined herself as transcending the risk of predation—we are those who eat but are never to be eaten—and

1 Her posthumously edited collection of essays, The Eye of the Crocodile (Plumwood 2012), presents this material powerfully. See also her 1999 essay "Being Prey" for a more detailed account of the crocodile attack itself, in The New Earth Reader: The Best of Terra Nova, edited by David Rothenberg and Marta Ulvaeus (Plumwood 1999, pp. 76-91). 
how utterly that perception diverges from reality. Philosopher James Hatley uses Kristevian language of the "uncanny goodness of being edible to bears": that same existential shock of realizing that other large predators encountered at an unlucky moment will happily take us for food. ${ }^{2}$ We are part of the food web, a fact most of us in our collective orientation to reality effectively screen from consciousness. The rest of the world is food; we are not.

Plumwood makes clear that this denial of being prey goes well beyond the natural urge to defend ourselves and our children from predation. She asserts that, in addition, we are collectively maintaining a sort of philosophical category error with regard to ourselves.

... there was something profoundly and incredibly wrong in what was happening, some sort of mistaken identity ... The creature was breaking the rules, was totally ... wrong to think I could be reduced to food. As a human being, I was so much more than food. It was a denial of, an insult to all I was to reduce me to [mere] food. ${ }^{3}$

Seeing herself in the crocodile's predatory gaze —and then its jaws—-forced her out of that delusion of categorical human inviolability into a reality that felt initially inconceivable:

I leapt through the eye of the crocodile into what seemed ... a parallel universe, one with completely different rules to the "normal universe." This harsh, unfamiliar territory was the Heraclitean universe where everything flows, where we live the other's death, die the other's life: the universe represented in the food chain. I was suddenly transformed in the parallel universe into the form of a small, edible animal whose death was of no more significance than that of a mouse...

It was because the world in which I was meat diverged so wildly from what I saw as reality that I could not recognize it as the world of my own everyday experience, and had to adopt the "parallel universe" fiction. But that was a measure of my delusion ... It has been a great struggle for me to recognize and reconcile with this harsh world as my own. ${ }^{4}$

Those who are Christian are increasingly facing our complicity in this long-standing delusion, in many places attempting to move beyond the anthropocentrism Lynn White and many others have observed in the tradition. Nevertheless, we have not yet awakened collectively to our profound vulnerability to and with all other creatures on Earth. The reforms needed to make possible the wide-scale shock of immersion in reality Plumwood experienced are complex and require attention on many levels. What would it take to invite us all out of our massive collective cosmological delusion and denial, and into reality? For Christians, I am convinced that a pivotal piece needed is change to the holiest rituals of our faith: specifically, the sacramental rites of baptism and Eucharist, the bodily experiences that most deeply crystallize, enact, and, in turn, nourish the Christian imagination and worldview.

For instance, in my 2016 essay, "Rewilding Christian Spirituality," I call for a return to the early church practice of baptizing in local waters, ending the sacred/profane symbolic dualism that enacts baptism into so-called "holy water," within a building considered "sacred space," in a special pool to which only humans are admitted, and from which these humans are considered to belong to a Body embraced into a paschal hope of glorious personal resurrection to eternal life. Returning the practice of baptism to the local creek, river, or ocean complexifies this theology considerably, both inviting and requiring the perception of this water as the holy water-demanding all the care and ethical political protection it truly deserves-and reconfiguring the meaning of baptism to center in literal immersion

\footnotetext{
James Hatley, "The Uncanny Goodness of Being Edible to Bears" (Hatley 2004, pp. 13-31).

Val Plumwood, "Meeting the Predator" (Plumwood 2012, pp. 11-12).

(Plumwood 2012, pp. 13-14).
} 
in this watershed, with the pollution and frogs, salmon and mosquitoes, and homeless encampments it actually contains (also, in the ocean, sharks—see, predation!): all of this somehow part of that body of Christ. ${ }^{5}$ And we need Eucharistic immersion into our actual vulnerability as literal food to the rest of the world.

In this article, therefore, I first trace the ways much Eucharistic ritual language reinforces this implicit or explicit separation between humans and the rest of the animal, creaturely, and natural world—creating thereby, in addition to the God/world or human/animal distinctions many have noted, a core human versus food dualism as well. Next, I locate the heart of the problem for Christians in views of Jesus's death and resurrection that insist that Jesus retains human form forever in his risen body and brings believers with him into resurrection, thus religiously grounding the "we are not meant to be food" delusion. Third, I explore insights from Eric Meyer regarding humans as food to other creatures along with what I see as the limits of his proposal-namely its confinement within that view of resurrection I find problematic. Finally, I develop a theologically and biologically more adequate view of death and resurrection, toward a Eucharistic vision and ritual practices in touch with reality. This paper is part of a larger project more fully addressing these questions and their theological and anthropological implications, to be titled Jesus in the Earth; so, just a sketch here.

\section{Eucharist: Who Eats Whom?}

Ritual studies scholars have long explored how rituals make meaning, or help individuals and communities negotiate complex transitions, or create and sustain worldviews and social structures. ${ }^{6}$ That ritual is a key dimension of how a given religious tradition inculcates its core vision of reality is a basic assumption of this paper. Jesuit Juan Mateos opens the world-changing effect of such ritually charged perception:

During a feast we feel ourselves transferred to a different world. A skeptic will call this an illusion because the world goes on just the same and no ladders appear to bear us to the sky. Is it really an illusion? ... Those who feast live in a new world, which is their own seen through prophetic eyes; they go out to meet the good world created by God and for them it is brother and sister not enemy. ${ }^{7}$

And liturgical theologian Robert Hovda notes,

Good liturgical celebration, like a parable, takes us by the hair of our heads, lifts us momentarily out of the cesspool of injustice we call home, and puts us in the promised and challenging reign of God, where we are treated like we have never been treated anywhere else ... where we are bowed to and sprinkled and censed and kissed and embraced and where we share equally among all a holy food and drink. ${ }^{8}$

5 “Rewilding Christian Spirituality" (Dahill 2016d). This essay appeared in slightly amended form as "Into Local Waters: Rewilding the Study of Christian Spirituality" (Dahill 2016b).

6 Catherine Bell, Ritual: Perspectives and Dimensions (Bell 1997); from a Christian liturgical perspective, see Gordon Lathrop, Holy Things: A Liturgical Theology (Lathrop 1998). With regard to sacramental theology in particular, Benjamin Stewart has demonstrated how the form of baptismal experience-full immersion or sprinkling-shapes participants' spontaneous, untutored articulation of what their baptism means (Stewart 2009). In relation to Eucharist, several recent works explore how this ritual might more profoundly shape human ethical, political, social, and ecological practices. Cláudio Carvalhaes traces insights around Eucharist and relationships of various kinds in Eucharist and Globalization (Carvalhaes 2013); in The Eucharist (Bieler and Schottroff 2007), Andrea Bieler and Luise Schottroff probe connections between Eucharistic practice and human bodily suffering, including the experience of torture; Angel F. Mendéz Montoya explores the profound physicality of food and eating (though not being eaten) in relation to a range of cultural contexts in Theology of Food (Mendéz Montoya 2009); and Hugh O'Donnell has written a powerfully poetic immersion into ecological connections in Eucharist and the Living Earth, new and revised edition (O'Donnell 2012).

7 Juan Mateos, in A Sourcebook about Liturgy (Huck 1994, p. 3).

8 Robert Hovda, in A Sourcebook about Liturgy (Huck 1994, p. 1). 
These quotes celebrate liturgy opening liberating new worldviews-but of course it can also reinforce our blind spots. The first thesis of this paper is that Eucharistic practices, precisely as powerful contributors to participants' conceptions of themselves and the world, can function to reinforce Christian convictions of human invulnerability to being eaten.

At first glance, this claim might seem counterintuitive, at least among worshipers of Catholic, Anglican, Lutheran, and Orthodox Eucharistic theology and piety who celebrate the physicality of the sacrament and Jesus's being eaten: his divine/human body and blood moving physically into one's own body, to become metabolized into one's own flesh, and pervading a fully sacramental cosmos. ${ }^{9}$ This devotional piety allows worshipers to worship and receive a physically vulnerable God who comes to feed body-selves, becoming knit into the very tissues and blood cells of worshipers. Here, the experience of Eucharistic physicality provides the courage to live ever more deeply into one's own physical vulnerability as the place of encounter with the divine. ${ }^{10}$ Martin Luther's 1527-28 Eucharistic debates with Ulrich Zwingli provide a locus classicus of the Lutheran insistence on and celebration of the raw physicality—even carnality—of the incarnation: the glory of God found not in some "pure" disembodied realm in heaven but precisely in human mouths, gullets, guts, and flesh. ${ }^{11}$ This insistence on flesh itself bearing Christ is a signal dimension of many eucharistic spiritualities, grounding an ethic often powerfully oriented to the ongoing health, feeding, and flourishing of real bodies around the world.

Yet for all its attention to bodies, and opening to the whole world sharing in sacramental beauty, even this highly incarnate Eucharistic piety does not generally attend to the full physical implications of the Eucharist-namely how worshipers' bodies become, in turn, food for other creatures. If the idea of God becoming food and feces was abhorrent to Zwingli, the idea of giving thanks for ticks or wolves or microbes or maggots eating us is equally unthinkable to climate-controlled, "pest"-destroying, corpse-encasing, resurrection-proclaiming Western Christians today. We don't go there-ever.

- For most Christians, Sunday by Sunday, the language and imagery of Eucharist describe an almost solely God-human reality. Nearly all the published Eucharistic prayers of the Catholic and Anglican churches, many of those of mainline traditions, and nearly all the communion language I've heard in my limited experience with nondenominational, evangelical, or other conservative churches, frame their thanksgiving around the story of human "salvation history" and believers' incorporation into the Body of Christ toward eternal life. ${ }^{12}$ At most, we might hear reference to the grains and grapes harvested to become the sacramental elements.

- In more creative mainline communities, including some renegade Anglicans and Catholics, other species do make their way into Eucharistic praying. Lions and lambs might peaceably attend an eschatological banquet at which there is no predation; and some communities now include reference to the Big Bang, or webs of life, or the soil, water, and farmworkers who bring us the grain and grapes. ${ }^{13}$ These are all salutary. Here too, however, pray-ers are located as eaters only,

9 See, e.g., Dorothy C. McDougall, The Cosmos as the Primary Sacrament (McDougall 2003); John Hart, Sacramental Commons (Hart 2006); Brian Douglas and Terence Lovat, “A Sacramental Universe” (Douglas and Lovat 2011).

10 The Eucharistic theologies cited in note 6 trace powerfully the interconnections between Eucharistic practices and human bodily experience of many kinds, including AIDS, torture, disability, illness, hunger, sexuality, joy, and kinship with the natural world. See also Emmanuel Falque, The Wedding Feast of the Lamb (Falque 2016).

11 Martin Luther, "That These Words of Christ, 'This Is My Body,' Still Stand Firm against the Fanatics," Luther's Works, edited by Robert H. Fischer. Vol. 37. (Luther 1961). A branch of philosophical hermeneutics centering in the body might be said to bring Luther's insistence on the materiality of God into new forms of nondualist thinking. See, e.g., Richard Kearney and Brian Treanor, Carnal Hermeneutics (Kearney and Treanor 2015). The emerging field of new materialist studies in religion similarly subverts classical God-world dualism, exploring the vibrancy or agency of matter itself; see Catherine Keller and Mary-Jane Rubenstein, eds., Entangled Worlds: Religion, Science, and the New Materialisms (Keller and Rubenstein 2017).

12 Eucharistic Prayers I, II, III, V, and VI in Evangelical Lutheran Worship (Augsburg Fortress 2006) fall into this category of more traditionally human-centered prayers, as do those of the Book of Common Prayer (Episcopal Church 1979) and The Roman Missal (United States Conference of Catholic Bishops 2010).

13 Eucharistic Prayers IV, VII, VIII, IX, and X in Evangelical Lutheran Worship (Augsburg Fortress 2006) display greater creationand human-justice orientation. See also the Eucharistic prayers of the Episcopal Church USA's Enriching Our Worship 
not those being eaten; and the salvation depicted, which might now encompass explicitly the entire biosphere or universe, still rests on promises of resurrection that keep humans separate into an individually perduring eternal life. Most of these rituals' location inside church buildings powerfully reinforces the sense that those who are really included — those being fed and oriented to a God reliably present within these holy walls-are solely humans, namely us.

- In the wildest communities I know, those of the Wild Church Network, ${ }^{14}$ worshiping permanently outdoors blows open that architectural symbolic of physical human separation from the larger world for this holiest of rites. Wild Church communities come from many traditions, with practices as diverse as our bioregions, but all gather outdoors, from city streets or parks to so-called wilderness, inviting people to experience Christian or interreligious ritual practice out in the thick of it all. These communities often include the place and its creatures explicitly as part of the Eucharistic assembly, scattering bread and pouring out wine for all who live here and addressing, attending to, or including the more-than-human world in diverse ways. Nevertheless, even here surprisingly little if any attention occurs in the practice of Eucharist or communion to our being food. ${ }^{15}$

I imagine that a handful of Wild Church leaders do play with this motif in their work-in fact, maybe they're so far off the grid that they missed my informal Facebook survey on this question. I imagine too that many in mainline, Catholic, and evangelical communities may be thinking along these lines, even if their community's ritual prayer may not reflect that. But these people are not the majority in any tradition, and it seems fair to conclude that, in practice, very few Christians are being regularly invited to consider deeply our raw physical vulnerability to other creatures-our being food-in Eucharist. When they come to worship, they find themselves in the human-centered gaze of a God who sees and feeds them, promising that they can remain human forever: an eternity of being a risen version of oneself. A vision where death doesn't mean losing one's form into full decomposition and diffuse re-embodiment into many other bodies upholds that fatal illusion that we will somehow avoid this ultimate vulnerability. ${ }^{16}$

Yet being eaten after death and metabolized into countless new tissues and lives—not rising to an eternal version of our present personhood-is a core biological reality of our lives. This prospect is not joyful for most, and Christians are happy to have the promise of an eternally human resurrection future instead, however vaguely that may be understood. But what if that resurrection vision is false? ${ }^{17}$ What if this attempt to withdraw our bodily availability from other creatures after death for heaven

(Episcopal Church 1998, pp. 57-65). Gail Ramshaw is a primary poet of emerging Eucharistic prayers; see the twenty prayers gathered in Pray, Praise, and Give Thanks (Ramshaw 2017).

14 https://www.wildchurchnetwork.com/.

15 I draw this highly unscientific conclusion from responses to a question I posted to the Wild Church Network (WCN) Facebook page in September 2019. I received thoughtful, spirited responses from ten WCN leaders who found the question provocative and intriguing but noted they did not themselves pray in this way with their communities.

16 The green burial movement is a salutary development in the larger spiritual and physical reconciliation of humans with our ultimate earthly edibility. Some Eastern Christian burial texts also include language pointing to our being eaten after death. Benjamin Stewart has surfaced fascinating examples. For instance: "Come, enter in, and see how many heroes sleep here, and are made dust for the moth and the worms in the abyss of Sheol. Come, enter in, and see how the great spoils which death hath captured are made worthless dust in the pit of Sheol," in Douglas Webb, "The Funeral Services of the Nestorian Church" (Webb 1983, p. 298). In an email of 9 November 2019, Stewart wrote, "while it's not as obvious here, the word 'gaping' could recruit some of the metaphorical sense of 'mouth' ... and thus that the earth itself is imagined as consuming the dead body: 'O gaping earth, receive the body formed from you by the hand of God, again returning to you as to its mother. What has been made in his image, the Creator has already reclaimed. O Earth, receive this body as your own.' Here's an online source: https://prostopinijefiles.wordpress.com/2018/10/01/burying-the-departed/."

17 I am not treating here the perhaps even more widespread North American Christian assertion of a body/soul dualism after death, in which one might be perfectly happy to consign one's body to the worms, while viewing the immortal soul as the part of oneself that "ascends" to heaven. Rather, this paper engages the traditional Christian insistence on the body's participation too in eternal life, its credal assertion of the "resurrection of the body." I do not have space to engage theologies such as, e.g., (Carnley 2019), who affirms the risen body of Christ in or as the Eucharistic elements and the Christian community but whose Platonic reading of Paul and the tradition also upholds the flesh/spirit split my proposal is attempting to overcome. See his chapter, "The Resurrection of the Body," (Carnley 2019, pp. 242-67). 
instead, denying our really and truly dying and becoming food, represents in fact the exact category error Plumwood names so powerfully? What if, Sunday after Sunday, even the most ecologically minded communities are unwittingly reinscribing this untruth on one another's psyches in ways that, across the global humanity Christians still dominate, contribute to the mass denial of our individual vulnerability to other creatures and thus, paradoxically, accelerate our species-wide vulnerability to extinction in the unsustainable alienation this denial has created? I challenge Christian communities to rethink the assumption that resurrection theology will miraculously defeat biology, and start exploring much more seriously and playfully how the core fact of our being food could pray-can we pray being prey?-constructively, in fact Eucharistically.

\section{What Kind of Resurrection?}

I am here moving into part two of my thesis: namely that the theology of the resurrection-Jesus's resurrection and believers' with him-is a central problem keeping the Christian tradition from being able to fully connect the Eucharistic dots. The sacramental enactment of Jesus's death and resurrection and believers' union with him is what primarily shields us ritually from facing our absolute participation in the meat economy of Earth. We are invited to experience ourselves as those destined for heaven instead. I see this problem in action dramatically in Eric Meyer's work.

Meyer's book Inner Animalities is a creative contribution on questions of predation, a topic central to his book exploring how the Christian tradition treats human animality. His is the only sustained work I know on what being food to other creatures has to do with Christian Eucharist, and he articulates a beautiful vision that centers in the reality of interspecies predation. ${ }^{18}$ Yet for all its originality, Meyer's vision is not ultimately convincing-precisely because his theological commitment to the resurrection obliges him to pull back from the full scope and implications of these questions.

Meyer centers his eschatological proposal in the Eucharistic faith claim that, despite being chewed and swallowed countless times every day over thousands of years in Eucharists going on ceaselessly around the world, Jesus is not thereby destroyed. He is endlessly eaten but never ceases to be fully intact and alive:

The resurrected wholeness of Christ's body is not contradicted by its endless consumption. ... The broken, betrayed, abandoned, and executed body of Jesus-a body preyed upon-is also a body whose flesh and blood continues to be consumed, even as Christ surely lives beyond suffering and death .... The eucharistic paradox in which Christ is consumed but not diminished offers a theological bridge across the problems of glorious consumption and predation. ${ }^{19}$

It's a brilliant idea: as with Jesus, the first fruits, so it will be in the ultimate resurrection of all things, eating and being eaten. Eternally, he posits, each species will still be eaten as they are on Earth, but without being destroyed, each endlessly persisting in its own reality despite being endlessly eaten, like Jesus. This eating will take place without hunger on the part of the predators-because in heaven there is "no need to incorporate energy from outside our bodies to survive," ergo no hunger-nor is there death, nor suffering for the prey. ${ }^{20}$ Yet if it's not the deepest gift and mercy to receive another creature's life, without which I will die-since in heaven there is only nonstop eternal life-then the logic of predation vanishes. That shuddering gratitude that comes only when you are very hungry indeed, and another animal or plant's self-gift infuses your body with its own literal cells as you moan

18 Eric Daryl Meyer, Inner Animalities: Theology and the End of the Human (Meyer 2018). Other work explores these questions with similar brilliance but without the connection to Eucharist. See Erika Murphy, "Devouring the Human: Digestion of a Corporeal Soteriology" (Murphy 2014); Denise Kimber Buell, “The Microbes and Pneuma that Therefore I Am” (Buell 2014); and Ernst Conradie, “To Eat or Be Eaten? That's the Question" (Conradie 2018).

19 (Meyer 2018, pp. 156-57).

20 (Meyer 2018, p. 160). 
to take it into yourself is why food is sacrament, is thanksgiving. ${ }^{21}$ Meyer's vision moves far out of synch with the actual ceaseless flow of life, what predation, food, hunger, and life on Earth really mean. The heart of the problem, what forces his predation-friendly bodily eschatological vision out of touch with biological reality, is Meyer's allegiance to the resurrection, his proposal's centering on a template (Jesus) of a body fixed forever in its singular earthly form, never dissolving kenotically into endless new wild lives. I question whether a Eucharistic vision clinging to Jesus's bodily human resurrection as its model can ever incorporate real predation, real eating, as these move into and through countless plant, animal, and mineral forms across countless generations of life.

Environmental ethicist Lisa Sideris has been insisting for some time on the necessary congruence between religion and biology, ${ }^{22}$ The latter work provides a caution against naively deifying science. and David Batchelder similarly calls for rituals and ritual practices that tell the truth. ${ }^{23}$ Phenomenologist and cultural ecologist David Abram is, however, perhaps the most thoroughgoing thinker I know in the depth and precision of his observations into the physical, sensory foundations of human perception and language. Regarding the intellectual process that gives rise to his writing, Abram notes:

It is a way of thinking that strives for rigor without forfeiting our animal kinship with the world around us - an attempt to think in accordance with the senses, to ponder and reflect without severing our sensorial bond with the owls and the wind. It is a style of thinking, then, that associates truth not with static fact, but with a quality of relationship. ${ }^{24}$

I too aspire to think "without forfeiting our animal kinship with the world around us," trusting that an incarnational theology can take seriously and not evade the core truths of our biological existence. ${ }^{25}$

\section{Eating and Being Eaten: A Eucharistic Vision}

In my "Rewilding Christian Spirituality" essay noted earlier, I described a piece of my own journey, as my long-standing experience of Jesus began to shift, culminating in an outdoor sabbatical during which "Jesus dissolved into the natural world," or, "the chancel walls gave way, and the whole world was now chancel." ${ }^{26}$ Only recently have I realized that, with this language, I was describing what I now consider a more satisfying view of Jesus' resurrection. If our theology is not to contradict

21 The severance of the practice of Eucharist from traditional practices of fasting in preparation for it (as well as diminished participation in Lenten fasting) means that the experience of real hunger in connection with Eucharist or in relation to one's daily food has also diminished in many places. On these connections, see Monika K. Hellwig, Eucharist and the Hunger of the World (Hellwig 1992), as well as Mary McGann, Meal that Reconnects (McGann 2020). Bill Plotkin explores the importance of fasting in relation not to religious practices like Eucharist but to the practice of extended wilderness immersion and spiritual deepening into a fully human maturity. See Soulcraft (Plotkin 2003, pp. 208-9, 213ff).

22 Lisa Sideris, Environmental Ethics, Ecological Theology, and Natural Selection (Sideris 2003), and Consecrating Science (Sideris 2017).

23 David B. Batchelder, "Baptismal Renunciations: Making Promises We Do Not Intend to Keep" (Batchelder 2007). Batchelder's essay is the springboard for my 2016 essay, "Life in All Its Fullness: Christian Worship and the Natural World" (Dahill 2016c), on bioregional adaptation of liturgical texts.

24 David Abram, Spell of the Sensuous (Abram 1997, p. 264).

25 This approach is Lutheran as well, in the sense noted above of Luther's insistence against Zwingli on the fundamental inherence of God in (sacramental) matter, as well as in Luther's hermeneutical privileging of the literal-rather than allegorical-meanings of scriptural texts. I here am similarly privileging the biologically literal truth of our lives, insisting that Christian theology must take it as seriously as biblical exegetes take the scriptural text. Dietrich Bonhoeffer embodies this Lutheran impulse in his unfinished Ethics, where he insists on the inseparability not merely of Jesus and the sacramental bread but of God and the world itself, joined fully and forever in the flesh of Jesus Christ. For Bonhoeffer, "reality" is visible only when this fundamental unity of God and the world in Jesus Christ is perceived, beheld. "There are not two realities, but only one reality, and that is God's reality revealed in Christ in the reality of the world" (Bonhoeffer 2005, p. 58). I explore these insights in "Addressing God with Names of Earth" (Dahill 2016a). In a paper delivered 22 November 2019, at the American Academy of Religion meeting in San Diego, I use them to propose a fundamental nondualism at the heart of Bonhoeffer's thinking. My use of the term "reality" in the present paper hews closer to Abram than to Bonhoeffer, in that I, too, sense the world itself and my sensory/animal engagement with it as the fundamental level of reality with which my theological thinking must reckon. I can use Bonhoeffer's language of Jesus Christ as that which (or the one who) so reconciles God and world that they are now inseparable-are in fact one reality—but I find Abram's biologically grounded thought, precisely as it opens to many forms of human symbolic meaning-making, to be even more compelling.

26 (Dahill 2016d, pp. 182, 181). 
biology, then Christians need to consider that we made a mistake (a category error, perhaps) in insisting that Jesus remain bound after death to the human shape of his life, ripping him out of his tomb in human form and refusing his body the much deeper primal grace of being allowed to decompose back into Earth, to rise again not as a mysterious human still able to eat and converse, but as a maggot Jesus, a trout Jesus eating the flies born from those maggots, a bear Jesus, a soil and grass and toad Jesus, juniper and cedar Jesus, and countless microbe and bacteria and fungi Jesuses as his molecules dispersed, as they surely longed to do, back into countless new forms of life: the resurrection! ${ }^{27}$

If we could grasp Jesus' own resurrection into the interspecies weirdness and glory and thrill of actual biological reality, might we be able to give Eucharistic thanks and celebrate our own hope of being resurrected into new forms and lives, our lives' bodily contribution toward real ongoing life, rather than the death our current human vision is creating on Earth? And if-by living closer to real hunger, perhaps, ramping way back our devouring of all that is-we were to grasp truly the intimacy and sweetness of being fed with the literal bodies and blood and flesh and life of actual living creatures, filled with that risen flesh of Jesus (or just miraculously themselves), and learn to give thanks not just for our food but to it in the most immediate and visceral I/Thou way, for that living creature's self-offering that will become remetabolized into my muscles and blood-if we could truly experience ritually and daily the gob-smacking miracle of all food as flesh of other creatures, our beloved real kin, more intimate to us than any lover as they literally come to comprise our own flesh, might we learn to give thanks also for that equal miracle of our own feeding of them, in our turn?

I want to live inside rites of baptism and Eucharist that take us so fully, completely, wildly inside our biological connection to other species and this whole beleaguered planet and the humans who urgently need our care along the way-so far inside all those relationships, physically and emotionally and intimately-that loving this life and these creatures, and humbly eating them and feeding them in turn, and listening to their needs, and acting to protect and cherish all this astonishing world is the Christian life itself: I want sacraments that enact this.

I'm haunted by a comment from a friend, also a scholar of Christian spirituality in heartfelt dialogue with contemporary eco-crises. Recounting a story of his preteen daughter and her recent existential encounter with the full implications of looming climate chaos and extinctions, my friend said, "nothing in [her] faith formation, or my faith formation, had prepared us to have this conversation, and to talk courageously and truthfully and faithfully about climate change." ${ }^{28}$ I hear this story as an uncommonly honest articulation of the failure of the Christian tradition to take even its most faithful and thoughtful members deeply enough into reality: a profound indictment.

Rites that tell the truth about reality mean, among other things, Christian ritual language-here, Eucharistic prayers-that break through our primal alienation as Plumwood's crocodile did, to help us experience our actual place in the actual biological world: a shock, to be sure, for those accustomed to be at the top of the food chain even unto eternal life-but a vision that is profoundly eucharistic, filled with gratitude and grace. A Christian vision doesn't have to contradict biology; it could invite us deeper into our own world, the miracle of being alive just as we are, here and now. My body really is meant to be eaten, and my great hope is to offer myself to become literal nourishment back to the suffering paradise that is Earth: I can do that by my body's excretion along the way-that's another chapter of this project-and I can give back in endless ways in my vocation and my citizenship and my

27 I am curious to explore a further aspect of Luther's Christological thinking, namely his insistence on the "ubiquity" of Jesus's risen body precisely in its flesh and physicality, after his ascension. That is, might this language of Luther's provide a more traditionally inflected (if, admittedly, also not universally accepted) way to speak of Jesus' resurrection into the physicality of all that is, the entire biosphere? On Luther and ubiquity, see Harold Ristau, "Ubiquity and Epiphany: Luther's Doctrine of the Lord's Presence in Space and Time" (Ristau 2013); Allen G. Jorgenson, "Luther, Ubiquity, and a Theology of the Public" (Jorgenson 2004).

28 Timothy Robinson, unscripted public comments (13 September 2019) following presentation of his paper, "Christian Hope (lessness) in the Anthropocene," at the BYU symposium, "On Being Vulnerable, Part II: Faith after the Anthropocene," at which the work gathered in this volume of Religions originated. 
love for the world and its creatures, including humans. And at the end, I can become the main course for nearby creatures, for a brief moment, in the huge glorious interspecies banquet that is life on Earth, to be fully remetabolized into countless other life forms, no personal me existing in some future realm. But I can't actually experience any of this explicitly, inter-species-ly, in any Christian Eucharist I know. This is my life's resurrection with Jesus, not some other heaven: my literal dissolving into Earth to feed its ongoing life. To know this reality in my bones-to receive precisely this ritually every week or every day in the practice of Eucharist-would be awesome grace. This is resurrection that does not undo kenosis but "deepens its mystery" further: new forms of life inseparable from the kenosis of one's human life. ${ }^{29}$

We who will dissolve with Jesus into Earth, our greatest joy, could then ritually ponder too what it might mean to die well, to give back as fully as possible to this divinely generous Earth, the source of our lives: this is my body ... this is my blood. And what would it mean to do so not only as individuals, as we must, but even to face our collective imperilment? What would it mean to die well as a nation, a society, a civilization, a species: to give back absolutely, as death requires and invites, to the present and future creatures who will receive our lives? These are our bodies, this is our blood ... This is the Eucharistic life.

So what kind of Eucharistic praying will open the crocodile shock-that jolt of knowing our radical vulnerability as meat to other creatures' jaws and mandibles and gullets, our resurrection with Jesus into their fur and feces, into blades of grass, snakes, and songbirds? I know many would not recognize my vision as Christian, stripped of the usual resurrection hope-which for many people is the entire point, the Gospel itself. But I offer it as the Eucharist we have needed all along, the Eucharist of reality, our re-entry to a world alive with gratitude and grace, wild energy and relationships, calling us to re-join it. Let's come home. With all who eat, as those who are eaten, let us learn to pray.

Funding: This research received no external funding.

Conflicts of Interest: The author declares no conflict of interest.

\section{References}

Abram, David. 1997. Spell of the Sensuous: Perception and Language in a More-than-Human World. New York: Vintage Books.

Augsburg Fortress. 2006. Evangelical Lutheran Worship. Minneapolis: Augsburg Fortress.

Batchelder, David B. 2007. Baptismal Renunciations: Making Promises We Do Not Intend to Keep. Worship 81: 409-25.

Bell, Catherine. 1997. Ritual: Perspectives and Dimensions. Oxford: Oxford University Press.

Bieler, Andrea, and Luise Schottroff. 2007. The Eucharist: Bodies, Bread, \& Resurrection. Minneapolis: Fortress Press.

Bonhoeffer, Dietrich. 2005. Ethics. Edited by Clifford J. Green. Dietrich Bonhoeffer Works (DBWE). Minneapolis: Fortress Press, vol. 6.

Buell, Denise Kimber. 2014. The Microbes and Pneuma that Therefore I Am. In Divinanimality: Animal Theory, Creaturely Theology. Edited by Stephen D. Moore. New York: Fordham University Press, pp. 63-87.

Carnley, Peter. 2019. The Reconstruction of Resurrection Belief. Eugene: Cascade Books.

Carvalhaes, Cláudio. 2013. Eucharist and Globalization: Redrawing the Borders of Eucharistic Hospitality. Eugene: Pickwick Books.

29 I am grateful to an anonymous peer reviewer for the insight that my view of resurrection "substantially deepens how kenosis remains in effect even in a resurrected creation. Resurrection ... only deepens its mystery." Recent theological work on "deep incarnation" provides a foundation for my thinking, and I build on its insights as to the inseparability of the flesh of Jesus from the rest of the biosphere here and in other work. See the essays contained in Incarnation: On the Scope and Depth of Christology, ed. Niels Henrik Gregersen (Gregersen 2015), especially those by Gregersen, Elizabeth Johnson, Denis Edwards, and Holmes Rolston; and Denis Edwards, Deep Incarnation: God's Redemptive Suffering with Creatures (Edwards 2019). Johnson's essay in the Gregersen volume takes up questions of "deep resurrection," but her proposal does not grapple with questions of predation, asserting only "the salvation of everything, even of matter, even of bodily life, even of the whole cosmos, reconciled in the mystery of God" (Johnson 2015, p. 150). 
Conradie, Ernst. 2018. To Eat or Be Eaten? That's the Question. In The Bloomsbury Handbook of Religion and Nature: The Elements. Edited by Laura Hobgood and Whitney Bauman. London and New York: Bloomsbury Academic, pp. 63-78.

Dahill, Lisa E. 2016a. Addressing God with Names of Earth. Currents in Theology and Mission 43: 27-31.

Dahill, Lisa E. 2016b. Into Local Waters: Rewilding the Study of Christian Spirituality. Spiritus: A Journal of Christian Spirituality 16: 141-65. [CrossRef]

Dahill, Lisa E. 2016c. Life in All Its Fullness: Christian Worship and the Natural World. Liturgy 31: 43-50. [CrossRef]

Dahill, Lisa E. 2016d. Rewilding Christian Spirituality: Outdoor Sacraments and the Life of the World. In Eco-Reformation: Grace and Hope for a Planet in Peril. Edited by Lisa E. Dahill and James B. Martin-Schramm. Eugene: Cascade Books, pp. 177-96.

Douglas, Brian, and Terence Lovat. 2011. A Sacramental Universe: Some Anglican Thinking. Pacifica: Australasian Theological Studies 24: 190-209. [CrossRef]

Edwards, Denis. 2019. Deep Incarnation: God's Redemptive Suffering with Creatures. Maryknoll: Orbis Books.

Episcopal Church. 1979. The Book of Common Prayer. New York: Seabury Press.

Episcopal Church. 1998. Enriching Our Worship. New York: Church Publishing.

Falque, Emmanuel. 2016. The Wedding Feast of the Lamb: Eros, the Body, and the Eucharist. Translated by George Hughes. New York: Fordham University Press.

Gregersen, Niels Henrik, ed. 2015. Incarnation: On the Scope and Depth of Christology. Minneapolis: Augsburg Fortress.

Hart, John. 2006. Sacramental Commons: Christian Ecological Ethics. New York: Rowman \& Littlefield.

Hatley, James. 2004. The Uncanny Goodness of Being Edible to Bears. In Rethinking Nature: Essays in Environmental Philosophy. Edited by Bruce V. Foltz and Robert Frodeman. Bloomington: Indiana University Press, pp. 13-31.

Hellwig, Monika K. 1992. Eucharist and the Hunger of the World. New York: Sheed and Ward.

Huck, Gabe. 1994. A Sourcebook about Liturgy. Chicago: Liturgy Training Publications.

Johnson, Elizabeth. 2015. Jesus and the Cosmos: Soundings in Deep Christology. In Incarnation: On the Scope and Depth of Christology. Edited by Niels Henrik Gregersen. Minneapolis: Augsburg Fortress, pp. 133-56.

Jorgenson, Allen G. 2004. Luther, Ubiquity, and a Theology of the Public. International Journal of Systematic Theology 6: 351-68. [CrossRef]

Kearney, Richard, and Brian Treanor, eds. 2015. Carnal Hermeneutics. New York: Fordham University Press.

Keller, Catherine, and Mary-Jane Rubenstein, eds. 2017. Entangled Worlds: Religion, Science, and the New Materialism. Transdisciplinary Theological Colloquia series; New York: Fordham University Press.

Lathrop, Gordon. 1998. Holy Things: A Liturgical Theology. Minneapolis: Fortress Press.

Luther, Martin. 1961. That These Words of Christ, 'This Is My Body', Still Stand Firm Against the Fanatics. In Luther's Works. Edited by Robert H. Fischer. Philadelphia: Fortress Press, vol.

McDougall, Dorothy C. 2003. The Cosmos as the Primary Sacrament: The Horizon for an Ecological Sacramental Theology. New York: Peter Lang.

McGann, Mary. 2020. Meal That Reconnects: Eucharistic Eating and the Global Food Crisis. Collegeville: Liturgical Press Academic.

Mendéz Montoya, Angel F. 2009. Theology of Food: Eating and the Eucharist. Malden: Wiley Blackwell.

Meyer, Eric Daryl. 2018. Inner Animalities: Theology and the End of the Human. New York: Fordham University Press.

Murphy, Erika. 2014. Devouring the Human: Digestion of a Corporeal Soteriology. In Divinanimality: Animal Theory, Creaturely Theology. Edited by Stephen D. Moore. New York: Fordham University Press, pp. 52-62.

O'Donnell, Hugh. 2012. Eucharist and the Living Earth, new and revised ed. Blackrock: The Columba Press.

Plotkin, Bill. 2003. Soulcraft: Crossing into the Mysteries of Nature and Psyche. Novato: New World Library.

Plumwood, Val. 1999. Being Prey. In The New Earth Reader: The Best of Terra Nova. Edited by David Rothenberg and Marta Ulvaeus. Cambridge: The MIT Press, pp. 76-91.

Plumwood, Val. 2012. Meeting the Predator. In The Eye of the Crocodile. Edited by Lorraine Shannon. Canberra: Australian National University Press.

Ramshaw, Gail. 2017. Pray, Praise, and Give Thanks: A Collection of Litanies, Laments, and Thanks at Font and Table. Minneapolis: Augsburg Fortress.

Ristau, Harold. 2013. Ubiquity and Epiphany: Luther's Doctrine of the Lord's Presence in Space and Time. Logia 22: $25-31$. 
Sideris, Lisa. 2003. Environmental Ethics, Ecological Theology, and Natural Selection. New York: Columbia University Press.

Sideris, Lisa. 2017. Consecrating Science: Wonder, Knowledge, and the Natural World. Berkeley: University of California Press.

Stewart, Benjamin J. 2009. The Role of Baptismal Water at the Vigil of Easter in the Liturgical Generation of Eco-Theology. Ph.D. dissertation, Emory University, Atlanta, GA, USA.

United States Conference of Catholic Bishops. 2010. The Roman Missal. Washington, DC: United States Conference of Catholic Bishops.

Webb, Douglas. 1983. The Funeral Services of the Nestorian Church. In Temple of the Holy Spirit: Sickness and Death of the Christian in the Liturgy: The Twenty-First Liturgical Conference Saint-Serge. Edited by Matthew J. O'Connell. New York: Pueblo Publishing Company, pp. 288-301.

C 2020 by the author. Licensee MDPI, Basel, Switzerland. This article is an open access article distributed under the terms and conditions of the Creative Commons Attribution (CC BY) license (http://creativecommons.org/licenses/by/4.0/). 